\title{
TINJAUAN STRUKTUR RUMAH SAKIT UMUM KELAS D KECAMATAN PASAR MINGGU JAKARTA SELATAN
}

\author{
M. Indra Nurseha \\ Program Studi Teknik Sipil Universitas Suryakancana \\ Wiratna Tri Nugraha \\ Dosen Program Studi Teknik Sipil Universitas Suryakancana
}

\begin{abstract}
ABSTRAK:
Rumah Sakit Umum Kelas D Kecamatan Pasar Minggu Jakarta Selatan pada awalnya adalah Puskesmas dan Rumah Sakit Bersalin, tapi dengan bertambahnya jumlah penduduk dan kebutuhan akan kesehatan, maka muncul alternatif untuk merehab puskesmas tersebut menjadi Rumah Sakit Umum Kelas D Kecamatan Pasar Minggu Jakarta Selatan. Desain-desain struktur yang digunakan pada bangunan ini memiliki banyak jenis ukuran atau dimensi, misalkan balok menggunakan 7 jenis dimensi, kolom menggunakan 2 jenis dimensi, dan pelat dengan tebal $12 \mathrm{~cm}$ dengan desain-desain tulangan yang telah terpasang. Tinjauan ini dilakukan untuk melihat bagaimana jika jenis-jenis balok, kolom, maupun pelat yang digunakan sebelumnya diganti dengan jenis-jenis yang baru, baik dalam segi dimensi maupun tulangan yang digunakan.

Desain baru yang direncanakan berdasarkan hasil analisis adalah kolom pada lantai 1-7 menggunakan dimensi $750 \mathrm{~mm} \times 750 \mathrm{~mm}$ dengan tulangan $16 \mathrm{D} 22 \mathrm{~mm}$, kolom pada atap menggunakan dimensi $300 \mathrm{~mm} \times 300 \mathrm{~mm}$ dengan tulangan $6 \mathrm{D} 22 \mathrm{~mm}$, balok arah X menggunakan dimensi $400 \mathrm{~mm} \times 700 \mathrm{~mm}$ dengan tulangan pada daerah tumpuan $13 \mathrm{D} 22 \mathrm{~mm}$ dan daerah lapangan $6 \mathrm{D} 22 \mathrm{~mm}$, balok arah Y menggunakan dimensi $300 \mathrm{~mm} \times 600 \mathrm{~mm}$ dengan tulangan pada daerah tumpuan $7 \mathrm{D} 22 \mathrm{~mm}$ dan daerah lapangan $5 \mathrm{D} 22 \mathrm{~mm}$, balok anak menggunakan dimensi $250 \mathrm{~mm} \times 500 \mathrm{~mm}$ dengan tulangan pada daerah tumpuan $5 \mathrm{D} 19 \mathrm{~mm}$ dan daerah lapangan $6 \mathrm{D} 19 \mathrm{~mm}$, pelat lantai dengan tebal $12 \mathrm{~cm}$ menggunakan tulangan rangkap pada lantai 2,4,5,6,7, dan dak menggunakan tulangan D10 - $200 \mathrm{~mm}$ pada arah X, D10 - $200 \mathrm{~mm}$ pada arah $Y$ daerah lapangan dan D10 - $50 \mathrm{~mm}$ pada daerah tumpuan, pelat lantai 3 menggunakan tulangan D10 - $200 \mathrm{~mm}$ pada arah X daerah lapangan dan D10 - $150 \mathrm{~mm}$ pada daerah tumpuan, D10 $200 \mathrm{~mm}$ pada arah $Y$ daerah lapangan dan D10 - $50 \mathrm{~mm}$ pada daerah tumpuan, pelat atap menggunakan tulangan D10 - 200 mm pada arah $X$ dan arah $Y$.
\end{abstract}

Kata kunci: Struktur gedung, tinjauan struktur, beton bertulang, SRPMM, SAP 2000 v.15, tulangan.

\section{A. PENDAHULUAN}

Kecamatan Pasar Minggu Jakarta Selatan merupakan daerah yang tingkat pertumbuhan ekonomi dan pertambahan jumlah penduduk sangat pesat. Pihak pemerintah, dalam hal ini Dinas Kesehatan DKI Jakarta bekerja sama membangun sarana dan prasarana kesehatan seperti rumah sakit unutuk memberikan pelayanan kesehatan bagi masyarakat khususnya daerah Kecamatan Pasar Minggu Jakarta Selatan.

Tercatat di daerah Kecamatan Pasar Minggu telah berdiri dan beroperasi sebuah Puskesmas dan Rumah Sakit Bersalin guna memberikan pelayanan kesehatan kepada masyarakat, akan tetapi bangunan ini dirasa masih kurang untuk melayani masyarakat secara menyeluruh, sehingga muncul alternatif untuk merehab total puskesmas tersebut menjadi Rumah Sakit Umum Kelas D Kecamatan Pasar Minggu Jakarta Selatan. Desain-desain struktur yang digunakan memiliki banyak jenis ukuran atau dimensi, misalkan balok menggunakan 7 jenis dimensi, kolom menggunakan 2 jenis dimensi, dan pelat dengan tebal $12 \mathrm{~cm}$ dengan desain-desain tulangan yang telah terpasang.

Tinjauan ini dilakukan untuk melihat bagaimana jika jenis-jenis balok, kolom, maupun pelat yang digunakan sebelumnya diganti dengan jenis-jenis yang baru, baik dalam segi dimensi maupun tulangan yang digunakan. 


\section{TUJUAN MASALAH}

Adapun tujuan dari penelitian tugas akhir ini adalah:

1. Meninjau kekuatan dan keamanan struktur kolom, balok, dan pelat lantai beton bertulang gedung Rumah Sakit Umum Kelas D Kecamatan Pasar Minggu Jakarta Selatan dengan menggunakan bantuan SNI, program SAP 2000 v.15 3D dan Pca Coloumn.

2. Meninjau rencana anggaran biaya (RAB) dan kurva $S$ yang dibutuhkan untuk bangunan struktur gedung rumah sakit tersebut.

\section{BATASAN MASALAH}

Penelitian tugas akhir ini memiliki beberapa batasan masalah, yaitu:

1. Analisis yang dilakukan hanya pada struktur atas yaitu bagian kolom, balok, dan pelat lantai utama tanpa lift, kolom lift, dinding geser, dan bangunan ramp.

2. Rencana anggaran biaya (RAB) dan kurva $S$ hanya menganalisa struktur atas, yaitu beton dan besi tulangan dengan menggunakan program Microsoft Spreedsheet Excel.

3. Perhitungan struktur akan dihitung dengan menggunakan program aplikasi komputer yaitu program SAP 2000 v. 15 3D dan Pca Coloumn.

4. Atap pada bangunan ini dijadikan beban pada lantai yang ada di bawahnya.

\section{B. METODOLOGI PENELITIAN 1. KOLOM}

Kolom adalah komponen struktur bangunan yang tugas utamanya menyangga beban aksial tekan vertikal dengan bagian tinggi yang tidak ditopang paling tidak tiga kali dimensi lateral terkecil (SK SNI T-15-199103).

Kolom adalah struktur utama yang berguna untuk meneruskan berat bangunan dan beban lain seperti beban hidup, beban angin, dan beban gempa untuk didistribusikan ke pondasi dan diteruskan ke dalam tanah. Kolom struktur portal dibuat menerus dari lantai bawah sampai lantai atas, letak kolom berada pada titik yang sama dan tidak boleh digeser. Ukuran kolom makin atas dapat makin kecil, sesuai dengan beban bangunan yang diterima, karena makin atas beban pun makin kecil.

\section{BALOK}

Balok adalah bagian dari struktur portal yang dirancang untuk menahan dan mentransfer beban menuju elemen-elemen kolom penopang. Balok berfungsi sebagai pengikat kolom-kolom untuk mempertahankan bentuk dan posisinya.

Tegangan yang timbul pada balok tergantung pada besar dan distribusi beban pada penampang balok. Semakin besar dimensi balok semakin kuat kemampuannya untuk memikul beban, tetapi menambah berat sendiri balok tersebut. Variabel utama dalam mendesain balok meliputi bentang, jarak antar kolom penopang, jenis dan besar beban, jenis material, ukuran dan bentuk penampang, serta cara penggabungan atau fabrikasi. Beberapa faktor yang merupakan prinsip-prinsip desain umum dalam perencanaan balok, yaitu:

1. Kontrol kekuatan dan kekakuan.

2. Variasi besaran material.

3. Variasi bentuk balok pada seluruh panjangnya.

4. Variasi kondisi tumpuan dan kondisi batas.

Balok umumnya menjadi kesatuan yang monolit dengan pelat. Pelat berlaku sebagai lapis sayap tekan yaitu sebagai komponen struktur yang bekerja pada dua arah lenturan saling tegak lurus, sedangkan balok berlaku sebagai badan.

\section{PELAT LANTAI}

Pelat lantai adalah struktur bangunan yang tidak berada di atastanah secara langsung. Pelat lantai dibingkai oleh balok yang kemudian ditopang oleh kolom-kolom bangunan.

Pada SNI 03-2847-2002, pelat lantai hanya menahan beban tetap (penghuni, perabotan, berat lapis keramik, berat sendiri pelat) yang bekerja dalam waktu lama. Sedangkan untuk beban tak terduga seperti gempa, angin, dan getaran tidak diperhitungkan.

Perencanaan dan hitungan pelat lantai dari beton bertulang harus mengikuti persyaratan yang tercantum dalam pedoman SK SNI T15-1991-03. Beberapa persyaratan tersebut antara lain:

1. Pelat lantai harus mempunyai tebal sekurang-kurangnya $12 \mathrm{~cm}$, sedang untuk pelat atap sekurang-kurangnya 7 $\mathrm{cm}$.

2. Pelat lantai menggunakan tulangan silang dengan diameter minimum $8 \mathrm{~mm}$. 
3. Pada pelat lantai yang tebalnya lebih dari $25 \mathrm{~cm}$ harus dipasang tulangan rangkap atas bawah.

4. Jarak tulangan pokok yang sejajar tidak kurang dari $2,5 \mathrm{~cm}$ dan tidak lebih dari $20 \mathrm{~cm}$ atau dua kali tebal pelat.

5. Semua tulangan pelat harus terlapisi beton setebal minimum $1 \mathrm{~cm}$, untuk melindungi baja dari karat, korosi, atau kebakaran.

3. PEMBEBANAN STRUKTUR

Beban-beban yang diperhitungkan dalam perencanaan gedung ini besarnya ditentukan oleh Peraturan Pembebanan Indonesia Untuk Gedung (PPIUG-1989).

Beban-beban yang diperhitungkan dalam perhitungan struktur adalah sebagai berikut:

1. Beban mati sendiri (DL) dari elemen struktur yang meliputi berat balok, kolom, pelat lantai, dan tangga.

2. Beban mati dari elemen tambahan (DL) yang meliputi dinding, keramik, plesteran, plumbing, mechanical electrical, plafond dan rangka plafond, waterproofing.

3. Beban hidup (LL) yang tergantung pada fungsi bangunan, yang dalam kasus ini gedung digunakan sebagai rumah sakit.

4. Beban gempa (Q), dalam kasus ini hanya ditinjau terhadap beban gempa statik ekuivalen.

\section{KOMBINASI BEBAN}

Kombinasi pembebanan yang digunakan mengacu pada SNI Beton 03-2847-2002, kombinasi bebana pada perhitungan struktur gedung dapat dirangkum sebagai berikut:

1. 1,4DL

2. $1,2 \mathrm{DL}+1,6 \mathrm{LL}$

3. $1,2 \mathrm{DL}+1 \mathrm{LL}+1 \mathrm{EX}+0,3 \mathrm{EY}$

4. $1,2 \mathrm{DL}+1 \mathrm{LL}-1 \mathrm{EX}-0,3 \mathrm{EY}$

5. $1,2 \mathrm{DL}+1 \mathrm{LL}+0,3 \mathrm{EX}+1 \mathrm{EY}$

6. $1,2 \mathrm{DL}+1 \mathrm{LL}-0,3 \mathrm{EX}-1 \mathrm{EY}$

7. $0,9 \mathrm{DL}+1 \mathrm{EX}+0,3 \mathrm{EY}$

8. $0,9 \mathrm{DL}-1 \mathrm{EX}-0,3 \mathrm{EY}$

9. $0,9 \mathrm{DL}+0,3 \mathrm{EX}+1 \mathrm{EY}$

10. $0,9 \mathrm{DL}-0,3 \mathrm{EX}-1 \mathrm{EY}$

Dimana:

$$
\begin{array}{lll}
\text { - } & \text { DL } & \text { : Beban mati } \\
\text { - } & \text { LL } & \text { : Beban hidup } \\
\text { - } & \text { E } & \text { : Beban gempa }
\end{array}
$$

Tanda \pm menyatakan arah beban yang bolakbalik. Beban gempa (E) dianggap bekerja $100 \%$ pada arah sumbu utama bersamaan dengan $30 \%$ pada arah tegak lurus sumbu utama.

\section{PERATURAN-PERATURAN}

Perhitungan konstruksi gedung ini memperhatikan ketentuan-ketentuan yang berlaku yang terdapat pada buku-buku pedoman antara lain:

1. Tata Cara Perhitungan Struktur Beton Untuk Bangunan Gedung (SNI 03-28472002).

2. Peraturan Pembebanan Indonesia Untuk Gedung dan Bangunan Lain (SNI 17271989).

3. Standar Perencanaan Ketahanan Gempa Untuk Struktur Bangunan Gedung (SNI03-1726-2002).

4. Tata Cara Perencanaan Struktur Baja Untuk Bangunan Gedung (SNI 03-17292002).

SAP 2000 v.15 3D

SAP 2000 merupakan sebuah program yang dikembangkan oleh perusahaan Computer \& Structure, Inc. Program SAP ini memiliki kelebihan dalam perancangan struktur baja dan beton agar dimensi yang digunakan bisa optimal dan ekonomis.

Program ini dapat membantu dalam perhitungan analisis struktur dan desain. Program ini digunakan untuk merancang, menganalisa, dan menampilkan geometri struktur, properti, dan hasil analisis. Hasil analisis ini berupa nilai-nilai yang selanjutnya digunakan untuk perhitunganperhitungan yang mempengaruhi struktrur, seperti tulangan pokok, tulangan geser, dll.

\section{PCA COLOUMN}

Pca Coloumn dapat digunakan untuk mendesain atau mengecek struktur kolom. Data-data yang diperlukan dalam analisis kolom menggunakan program Pca Coloumn ini adalah momen lentur dan gaya aksial tekan yang dipikul oleh kolom. Dari kedua data ini, Pca Coloumn akan menampilkan diagram interaksi, dimana diagram ini adalah diagram yang menunjukan hubungan momen lentur dan gaya aksial tekan yang dapat dipikul oleh elemen kolom pada kondisi batas. Jika semua beban masih berada di dalam garis diagram, maka kolom tersebut mampu menahan beban tersebut (aman), jika beban berada di luar garis diagram dapat disimpulkan bahwa kolom tidak mampu menahan beban. Jika hal ini terjadi, alternatif yang bisa dilakukan diantaranya adalah menaikan mutu beton, 
menambah jumlah tulangan, dan memperbesar ukuran kolom.

\section{ANALISA PEMBEBANAN}

Beban yang bekerja pada struktur diambil dari berat sendiri struktur, beban mati tambahan dari komponen pendukung, dan beban hidup yang ditentukan pada tabel 1 dan tabel 2, Tata Cara Perencanaan Pembebanan untuk Rumah dan Gedung, SNI 03-1727-1989.

Beban mati diuraikan menjadi beban mati akibat berat sendiri dan beban mati tambahan.

1. Beban mati pada pelat lantai
a. Finishing $(2,5 \mathrm{~cm})$
$53 \mathrm{Kg} / \mathrm{m}^{2}$
b. Pasangan keramik
$24 \mathrm{Kg} / \mathrm{m}^{2}$
c. ME
d. Plafond dan rangka
$25 \mathrm{Kg} / \mathrm{m}^{2}$
e. Sanitasi/plumbing
$18 \mathrm{Kg} / \mathrm{m}^{2}$
f. Partisi
$30 \mathrm{Kg} / \mathrm{m}^{2}$
$100 \mathrm{Kg} / \mathrm{m}^{2}$

2. Berat mati pada pelat atap
a. Waterproofing
b. ME
$105 \mathrm{Kg} / \mathrm{m}^{2}$
c. Plafond dan rangka
$25 \mathrm{Kg} / \mathrm{m}^{2}$
$18 \mathrm{Kg} / \mathrm{m}^{2}$
d. Sanitasi/plumbing
$30 \mathrm{Kg} / \mathrm{m}^{2}$

3. Beban tambahan lainnya, yaitu dinding. Beban ini tergantung pada tinggi dinding dan panjang balok yang menahan dinding tersebut.

Beban hidup merupakan beban yang bukan berasal dari berat komponen-komponen bangunan.

1. Beban hidup pada pelat lantai sebesar $250 \mathrm{Kg} / \mathrm{m}^{2}$

2. Beban hidup pada pelat atap sebesar 100 $\mathrm{Kg} / \mathrm{m}^{2}$

Beban gempa menggunakan perhitungan sistem rangka pemikul momen menengah (SRPMM), dikarenakan bangunan terletak di wilayah gempa zona 4 dan beban gempa yang direncanakan adalah beban gempa statik ekivalen.

\begin{tabular}{|r|r|r|}
\hline \multirow{2}{*}{ Fix=Fiy (Kg) } & Untuk Tiap Portal $x$ & \multicolumn{1}{|c|}{ Untuk Tiap Portal y } \\
\cline { 2 - 3 } & \multicolumn{1}{|c|}{$1 / 5 . \mathrm{Fi}(\mathrm{Kg})$} & $1 / 4 . \mathrm{Fi}(\mathrm{Kg})$ \\
\hline 25275,85885 & 5055,17177 & 6318,96471 \\
\hline 40945,59862 & 8189,11972 & 10236,39965 \\
\hline 66678,36725 & 13335,67345 & 16669,59181 \\
\hline 80220,80909 & 16044,16182 & 20055,20227 \\
\hline 89409,71852 & 17881,94370 & 22352,42963 \\
\hline 109392,03598 & 21878,40720 & 27348,00899 \\
\hline 91405,05131 & 18281,01026 & 22851,26283 \\
\hline
\end{tabular}

\section{DIMENSIONING STRUKTUR}

Dimensi-dimensi pada struktur yang digunakan adalah:

1. Pelat, dimensi pelat yang digunakan yaitu tebal $12 \mathrm{~cm}$.
2. Balok, dimensi balok yang akan dianalisa yaitu balok dengan gaya dalam terbesar dari tiap lantai, yaitu:
a. Balok $700 \mathrm{~mm}$ x $400 \mathrm{~mm}$
b. Balok $600 \mathrm{~mm} \times 300 \mathrm{~mm}$
c. Balok $500 \mathrm{~mm}$ x $250 \mathrm{~mm}$

Kolom, dimensi kolom yang akan dianalisa adalah kolom dengan gaya dalam terbesar, yaitu kolom $750 \mathrm{~mm}$ x $750 \mathrm{~mm}$.

\section{PENULANGAN PELAT}

Tulangan pelat lantai yang digunakan adalah baja tulangan ulir (deform) dengan mutu fy $=400$ Mpa untuk $\mathrm{D} \geq 10 \mathrm{~mm}$ dan mutu beton $\mathrm{fc}=25 \mathrm{Mpa}$ dengan selimut beton 25 $\mathrm{mm}$. Perhitungan menggunakan sistem pelat dua arah yaitu pelat dengan perbandingan panjang dan lebar kurang dari sama dengan 2,5 (Ly/Lx $\leq 2,5)$, tulangan dipasang pada dua arah yang saling tegak lurus.

1. Pelat lantai 2, 4, 5, 6, 7, dan dak

Pelat yang dianalisa adalah pelat dengan $\mathrm{Lx}$ $=3 \mathrm{~m}$ dan $\mathrm{Ly}=8 \mathrm{~m}$.

Beban-beban yang diterima oleh pelat yaitu:
a. Beban mati
$=438 \mathrm{~kg} / \mathrm{m}^{2}$
b. Beban hidup
$=250 \mathrm{~kg} / \mathrm{m}^{2}$
c. Beban terfaktor
$=925,6 \mathrm{~kg} / \mathrm{m}^{2}$

Menghitung nilai momen yang bekerja pada pelat

Mlx $(+)=0,001 \cdot q u \cdot \mathrm{Lx}^{2} \cdot \mathrm{x}$

Mly $(+)=0,001 \cdot q u \cdot \mathrm{Ly}^{2} \cdot \mathrm{x}$

$\operatorname{Mtx}(-)=0,001 \cdot q u \cdot L^{2} \cdot x$

Mty (-) $=0,001 \cdot q u \cdot \mathrm{Ly}^{2} \cdot \mathrm{x}$

Menghitung jarak tulangan yang digunakan pada pelat:

a. Kontrol tulangan

$\mathrm{K}=\frac{M u}{\emptyset b d^{2}}=\frac{524,832 \cdot 10^{4}}{0,8 \cdot 1000 \cdot 90^{2}}=0,81 \mathrm{Mpa}$

$\rho=0.85 \times \frac{f c}{f y} \times\left[1-\sqrt{1-\frac{2 . K}{0,85 . f c}}\right]$

$=0.85 \times \frac{25}{400} \times\left[1-\sqrt{1-\frac{2.0,81}{0,85.25}}\right]=0,0021$

$\rho \min =\frac{1,4}{f y}=\frac{1,4}{400}=0,0035$

$\rho \mathrm{b}=0,85 \cdot \beta_{1} \cdot \frac{f c}{f y}\left[\frac{600}{f y+600}\right]$

$=0,85 \cdot 0,85 \cdot \frac{25}{400}\left[\frac{600}{400+600}\right]=0,0271$

$\rho \max =0,75 . \rho b=0,0203$

As perlu $=\rho \cdot b \cdot d=315 \mathrm{~mm}^{2}$

As $\max =\rho \max . b \cdot d=1827 \mathrm{~mm}^{2}$

s perlu $=\frac{1 / 4 \pi D^{2} b}{A s \text { perlu }}=\frac{1 / 4 \pi 10^{2} .1000}{315}$

$=249,333 \mathrm{~mm}$

$\mathrm{s} \max =2 . h=2.120=240 \mathrm{~mm}$

Jarak tulangan (s) yang dipakai yaitu 200 $\mathrm{mm}$. 
$\mathrm{As}=\frac{1 / 4 \pi D^{2} b}{s}=\frac{\frac{1}{4} \pi 10^{2} .1000}{200}$

$=392,5 \mathrm{~mm}^{2}>$ As perlu $\left(315 \mathrm{~mm}^{2}\right)$

b. Kontrol momen pada pelat

Mlx $=524,832 \mathrm{Kgm}$

$\varnothing \mathrm{Mn}=\varnothing \times$ As terpasang $\mathrm{x}$ fy $\mathrm{x} \mathrm{jd}$

$=10,4562 \mathrm{kNm}=1045,62 \mathrm{Kgm}$

$\varnothing \mathrm{Mn}(1045,62)>\operatorname{Mlx}(524,832)$

c. Kontrol lendutan

$\mathrm{Ec}=23500 \mathrm{Mpa}$

$\mathrm{Es}=200000 \mathrm{Mpa}$

$\mathrm{qD}+\mathrm{qL}=438+250=6,88 \mathrm{~N} / \mathrm{mm}$

$\mathrm{Lx}=3000 \mathrm{~mm}$

Lendutan ijin $=\mathrm{Lx} / 240=12,5 \mathrm{~mm}$

$\mathrm{Ig}=1 / 12 \cdot \mathrm{b} \cdot \mathrm{h}^{3}=144 \cdot 10^{6} \mathrm{~mm}^{4}$

$\mathrm{fr}=0,7 \sqrt{f c}=3,5 \mathrm{Mpa}$

$\mathrm{n}=\mathrm{Es} / \mathrm{Ec}=8,511$

$\mathrm{c}=\mathrm{n} \cdot \frac{A s}{b}=3,341 \mathrm{~mm}$

Icr $=\left(1 / 3 \cdot b \cdot c^{3}\right)+\left(\right.$ n.As. $\left.(d-c)^{2}\right)$

$=25099365,68 \mathrm{~mm}^{4}$

$\mathrm{yt}=\mathrm{h} / 2=60 \mathrm{~mm}$

Mcr $=\frac{(\text { fr. } I g)}{y t}=84.10^{5} \mathrm{Mpa}$

$\mathrm{Ma}=1 / 8 \cdot q \cdot \mathrm{Lx}^{2}=1 / 8 \cdot 6,88 \cdot 3000^{2}$

$=7740000 \mathrm{Nmm}$

$\mathrm{Ie}=\left(\frac{M c r}{M a}\right)^{3} \times I g+\left(1-\left(\frac{M c r}{M a}\right)^{3}\right) \times I c r$

$=151984448 \mathrm{~mm}^{4}$

Lendutan seketika akibat beban mati dan beban hidup

$\delta e=\left(\frac{5}{384}\right) \cdot \mathrm{q} \cdot \mathrm{Lx}^{4} /($ Ec.Ie $)=2,032 \mathrm{~mm}$

$\rho=\frac{A s}{b . d}=\frac{392,5}{1000.90}=0,00436$

$\mathrm{T}=2$

$\lambda=\frac{T}{1+50 \rho}=\frac{2}{1+50.0,00436}=1,642$

$\delta g=\lambda \frac{5}{384} \frac{q L x^{4}}{E c . I e}=3,336 \mathrm{~mm}$

$\delta$ total $=\delta e+\delta g=2,032+3,336$

$=5,368 \mathrm{~mm}<12,5 \mathrm{~mm}$ (aman)

Dengan menggunakan metode yang sama, dapat dihitung pula momen-momen yang bekerja pada pelat yang lain.

2. Pelat lantai 3

Pelat yang dianalisa adalah pelat dengan Lx $=3,85 \mathrm{~m}$ dan $\mathrm{Ly}=8 \mathrm{~m}$. Dalam perhitungan beban, momen-momen yang diterima oleh pelat, jarak tulangan, kontrol momen, dan kontrol lendutan yang dilakukan rumusrumus yang digunakan tidak berbeda dengan pelat lantai sebelumnya.

3. Pelat lantai atap

Pelat yang dianalisa adalah pelat dengan Lx $=3,2 \mathrm{~m}$ dan $\mathrm{Ly}=4 \mathrm{~m}$. Jika dilihat dari segi ukuran, pelat ini tidak masuk dalam kategori pelat dua arah, tapi dalam pelaksanaan di lapangan dan perhitungan pelat dilakukan secara dua arah.

Beban-beban yang diterima oleh pelat yaitu:

1. Beban mati $=466 \mathrm{~kg} / \mathrm{m}^{2}$

2. Beban hidup $\quad=100 \mathrm{~kg} / \mathrm{m}^{2}$

3. Beban terfaktor $\quad=719,2 \mathrm{~kg} / \mathrm{m}^{2}$

Sama seperti sebelumnya perhitungan momen-momen yang diterima oleh pelat, jarak tulangan, kontrol momen, dan kontrol lendutan yang dilakukan rumus-rumus yang digunakan tidak berbeda dengan pelat lantai sebelumnya.

\section{PENULANGAN BALOK}

Balok yang dianalisa merupakan balok dengan nilai gaya dalam terbesar dari setiap lantai. Tulangan yang digunakan adalah baja ulir (deform) dengan mutu fy $=400 \mathrm{Mpa}$ untuk $\mathrm{D} \geq 10 \mathrm{~mm}$ dan beton dengan mutu $\mathrm{fc}$ $=25 \mathrm{Mpa}$.

1. Balok induk arah $\mathrm{X}$ dengan data sebagai berikut:

Dimensi balok $\quad 0,4 \mathrm{~m} \mathrm{x} 0,7 \mathrm{~m}$

Tulangan pokok D22 $\mathrm{mm}$

Tulangan sengkang D10 mm

Selimut beton $\quad 50 \mathrm{~mm}$

Momen rencana akibat beban terfaktor adalah:

Mut $_{1} \quad: 733,0148 \mathrm{kNm}$

Mut $_{2} \quad: 106,4687 \mathrm{kNm}$

Mul : $310,6256 \mathrm{kNm}$

$\mathrm{Vu}: 367,474 \mathrm{kN}$

$\mathrm{d}_{\mathrm{ix}}=\mathrm{h}-\mathrm{sb}-\mathrm{s}-1 / 2 \mathrm{D}=629 \mathrm{~mm}$

$\mathrm{jd}_{\mathrm{ix}} \quad=0,875 \mathrm{x} \mathrm{d}_{\mathrm{ix}}=550,375 \mathrm{~mm}$

Luas tulangan yang diperlukan pada tumpuan

As perlu $=\frac{M u}{\text { Q.fy.jd }}=5122,485 \mathrm{~mm}^{2}$

Tulangan yang digunakan, yaitu:

$\mathrm{n}=\frac{\text { As perlu }}{\text { Luas tulangan }}=13,376 \approx 14$ buah

Digunakan tulangan 14 D22 mm $(\mathrm{A}=5324$ $\mathrm{mm}^{2}$ )

Luas tulangan yang diperlukan pada lapangan

As perlu $=\frac{M u}{\text { o.fy.jd }}=2170,727 \mathrm{~mm}^{2}$

Tulangan yang digunakan, yaitu:

$\mathrm{n}=\frac{\text { As perlu }}{\text { Luas tulangan }}=5,7104 \approx 6$ buah

Digunakan tulangan 6 D22 mm $(\mathrm{A}=2281,7$ $\mathrm{mm}^{2}$ )

Nilai a dan cek kondisi tulangan tumpuan

$\mathrm{a}=\frac{\text { As.fy }}{\text { 0,85.fc.b}}=241,058 \mathrm{~mm}$

$\mathrm{Jd}$ baru $=\mathrm{d}-\frac{a}{2}=508,471 \mathrm{~mm}$

As baru $=\frac{M u}{\text { Q.fy.jd }}=5544,638 \mathrm{~mm}^{2}$ 
Tulangan yang digunakan, yaitu:

$\mathrm{n}=\frac{\text { As perlu }}{\text { Luas tulangan }}=14,586 \approx 15$ buah

Digunakan tulangan $15 \mathrm{D} 22 \mathrm{~mm}(\mathrm{~A}=$ $5704,286 \mathrm{~mm}^{2}$ )

Kontrol kuat momen tulangan tumpuan

$\varnothing$ Momen rencana $\geq$ Momen ultimate

$\varnothing . \mathrm{Mn}=\varnothing \times$ As perlu baru $\mathrm{x}$ fy $\mathrm{x}$ jd baru

$=0,8 \times 5544,638 \times 400 \times 508,471$

$=902,172 \mathrm{kNm}>\mathrm{Mu}=733,0148 \mathrm{kNm}$

Dari data yang didapatkan, nilai $\varnothing . \mathrm{Mn}$ terlalu besar, tulangan yang digunakan dicoba 13 D22 $\mathrm{mm}$.

$\varnothing . \mathrm{Mn}=\varnothing \times$ As perlu baru $\mathrm{x}$ fy $\mathrm{x}$ jd baru

$=0,8 \times 4941,725 \times 400 \times 508,471$

$=804,1 \mathrm{kNm}>\mathrm{Mu}=733,0148 \mathrm{kNm}$

Jadi tulangan yang digunakan 13 D22 mm, di bagian atas balok 8 D22 mm, dan di bagian bawah balok 5 D22 mm.

$\mathrm{Mu}_{1}=488,677 \mathrm{kNm}$

$\mathrm{Mu}_{2}=244,338 \mathrm{kNm}$

As terpasang atas $=\mathrm{n} \times$ Luas tulangan

$=8.380,133=3041,064 \mathrm{~mm}$

As terpasang bawah $=\mathrm{n} \quad \mathrm{x}$ Luas tulangan

$=5.380,133=1900,666 \mathrm{~mm}$

Dari data mengenai tulangan yang digunakan, diperlukan cek kuat tulangan yang digunakan:

$\varnothing . \mathrm{Mn}_{1}=\varnothing \times$ x As terpasang $\mathrm{x}$ fy $\mathrm{x}$ jd baru

$=0,8.3041,064.400 .508,471$

$=494,814 \mathrm{kNm}$

$\varnothing \cdot \mathrm{Mn}_{2}=\varnothing$. As terpasang $\mathrm{x}$ fy $\mathrm{x}$ jd baru

$=0,8.1900,666.400 .508,471$

$=309,259 \mathrm{kNm}$

$\mathrm{Mr}=\varnothing \cdot \mathrm{Mn}_{1}+\varnothing \cdot \mathrm{Mn}_{2}$

$=494,814+309,259$

$=804,073 \mathrm{kNm}$

$\mathrm{Mr}>\mathrm{Mu}_{1}+\mathrm{Mu}_{2}$

804,073 kNm>733,0148 kNm (aman)

Kontrol kuat momen tulangan lapangan

$\varnothing$ Momen rencana $\geq$ Momen ultimate

Balok induk arah " $\mathrm{X}$ " tulangan lapangan

$\varnothing . \mathrm{Mn}=\varnothing \times$ As perlu baru $\mathrm{x}$ fy $\mathrm{x}$ jd baru

$=0,8 \times 2067,213 \times 400 \times 577,9345$

$=382,308 \mathrm{kNm}>\mathrm{Mu}=310,6256 \mathrm{kNm}$

Jadi tulangan yang digunakan 6 D22 mm, di bagian atas balok 2 D22 mm, dan di bagian bawah balok 4 D22 $\mathrm{mm}$.

$\mathrm{Mu}_{1}=103,542 \mathrm{kNm}$

$\mathrm{Mu}_{2}=207,084 \mathrm{kNm}$

As terpasang atas $=\mathrm{n} \times$ Luas tulangan

$=2.380,133=760,266 \mathrm{~mm}$

As terpasang bawah $=\mathrm{n} \times$ Luas tulangan $=4.380,133=1520,532 \mathrm{~mm}$
Dari data mengenai tulangan yang digunakan, diperlukan cek kuat tulangan yang digunakan:

$\varnothing . \mathrm{Mn}_{1}=\varnothing \mathrm{x}$ As terpasang $\mathrm{x}$ fy $\mathrm{x} \mathrm{jd}$ baru

$=0,8.760,266 \cdot 400.577,9345$

$=140,603 \mathrm{kNm}$

$\varnothing . \mathrm{Mn}_{2}=\varnothing$. As terpasang $\mathrm{x}$ fy $\mathrm{x} \mathrm{jd}$ baru

$=0,8 \cdot 1520,532 \cdot 400.577,9345$

$=281,206 \mathrm{kNm}$

$\mathrm{Mr}=\varnothing \cdot \mathrm{Mn}_{1}+\varnothing \cdot \mathrm{Mn}_{2}$

$=140,603+281,206$

$=421,809 \mathrm{kNm}$

$\mathrm{Mr}>\mathrm{Mu}_{1}+\mathrm{Mu}_{2}$

$421,809 \mathrm{kNm}>310,6256 \mathrm{kNm}$ (aman)

Mengecek kondisi tulangan

$\rho$ terpasang $\leq \rho \max$

$\rho \mathrm{b}=\frac{0,85 . f c . \beta 1 .}{f y} \cdot \frac{600}{(600+f y)}=0,0271$

$\rho \max =0,75 \times \rho b=0,020325$

Cek tulangan max pada tulangan tumpuan

Balok induk arah " $\mathrm{X}$ "

$\rho=\frac{\text { As perlu }}{\text { bxd }}=\frac{5544,638}{400.629}$

$=0,02203>\rho \max =0,020325$

Karena dengan tulangan sebanyak 15 D22 mm, nilai $\rho$ melebihi $\rho$ max maka tulangan bisa diganti dengan 13 D22 mm.

$\rho=\frac{\text { As perlu }}{\text { b xd }}=\frac{4941,729}{400.629}$

$=0,0196<\rho \max =0,020325$

Cek tulangan max pada tulangan lapangan

Balok induk arah " $\mathrm{X}$ "

$\rho=\frac{\text { As perlu }}{\text { bxd }}=\frac{2067,213}{400.629}$

$=0,00822<\rho \max =0,020325$

2. Balok induk arah $\mathrm{Y}$ dengan data sebagai berikut:

Dimensi balok $\quad 0,3 \mathrm{~m} \times 0,6 \mathrm{~m}$

Tulangan pokok D22 $\mathrm{mm}$

Tulangan sengkang D10 mm

Selimut beton $\quad 50 \mathrm{~mm}$

Momen rencana akibat beban terfaktor adalah:

Mut $\quad: 191,8254 \mathrm{kNm}$

Mut $_{2} \quad: 302,4283 \mathrm{kNm}$

Mul : $198,4513 \mathrm{kNm}$

$\mathrm{Vu} \quad: 245,71 \mathrm{kN}$

Perhitungan yang dilakukan untuk mencari tulangan diawali dengan mencari tinggi efektif penampang, lengan momen, luas tulangan yang diperlukan, tulangan yang digunakan, nilai a dan cek kondisi tulangan, kontrol kuat momen tulangan, cek kondisi tulangan, dan cek tulangan max pada tulangan pada jenis balok ini sama dengan perhitungan yang dilakukan pada balok 
induk arah $\mathrm{X}$ baik pada tulangan tumpuan maupun tulangan lapangan.

3. Balok anak dengan data sebagai berikut:

Dimensi balok $\quad 0,25 \mathrm{~m} \mathrm{x} 0,5 \mathrm{~m}$

Tulangan pokok D19 mm

Tulangan sengkang D10 mm

Selimut beton $\quad 50 \mathrm{~mm}$

Momen rencana akibat beban terfaktor adalah:

Mut $_{1}$

$\mathrm{Mut}_{2}$

Mul

: $137,1076 \mathrm{kNm}$

: $106,2457 \mathrm{kNm}$

: $154,7776 \mathrm{kNm}$

$\mathrm{Vu}$

: $112,814 \mathrm{kN}$

Perhitungan yang dilakukan untuk mencari tulangan diawali dengan mencari tinggi efektif penampang, lengan momen, luas tulangan yang diperlukan, tulangan yang digunakan, nilai a dan cek kondisi tulangan, kontrol kuat momen tulangan, cek kondisi tulangan, dan cek tulangan max pada tulangan pada jenis balok ini sama dengan perhitungan yang dilakukan pada balok induk arah $\mathrm{X}$ baik pada tulangan tumpuan maupun tulangan lapangan.

4. Tulangan gesek

Tulangan geser dianalisa pada balok yang telah dianalisa sebelumnya, dan telah ditentukan jumlah tulangan yang dibutuhkan, baik untuk tulangan tumpuan maupun tulangan lapangan.

a. Balok induk arah $\mathrm{X}$

Dimensi balok $\quad: 0,7 \mathrm{~m} \mathrm{x} 0,4 \mathrm{~m}$

Gaya geser $(\mathrm{Vu}) \quad: 367,474 \mathrm{kN}$

Digunakan tulangan geser diameter 10 dengan 2 kaki

$\mathrm{Av}=2\left(1 / 4 \times \pi \times \mathrm{D}^{2}\right)$

$=2\left(1 / 4 \times \pi \times 10^{2}\right)$

$=157,1 \mathrm{~mm}^{2}$

Kapasitas penampang beton terhadap gaya geser

$\mathrm{Vc}=\frac{1}{6} \cdot \sqrt{f c} \cdot \mathrm{b} \cdot \mathrm{d}=\frac{1}{6} \cdot \sqrt{25} \cdot 400.629$

$=209666,6667 \mathrm{~N}=209,67 \mathrm{kN}$

Memeriksa perbandingan antara gaya geser $\mathrm{Vu}$ dengan kapasitas penampang beton

(Vc)

$\mathrm{Vc} \quad=209,67 \mathrm{kN}$

$\varnothing \mathrm{Vc} \quad=157,2525$

$1 / 2 \varnothing \mathrm{Vc}=78,63 \mathrm{kN}$

$\mathrm{Vu}=367,474 \mathrm{kN}>1 / 2 \varnothing \mathrm{Vc}=78,63 \mathrm{kN}$

Dengan melihat perbandingan ini, maka diperlukan tulangan geser.

Spasi maksimum

$\mathrm{S}$ maks $=0,5 \cdot \mathrm{d}=0,5 \cdot 629=314,5 \mathrm{~mm}$

$\mathrm{s} \leq \frac{3 . A v \cdot f y}{b}=\frac{3.157 .400}{400}=471 \mathrm{~mm}$, atau $\mathrm{s} \leq \frac{1200}{75} \frac{A v \cdot f y}{\sqrt{f c} \cdot b w}=\frac{1200}{75} \frac{157.400}{\sqrt{25.400}}$

$=502,4 \mathrm{~mm}$

Jarak antar sengkang yang dibutuhkan

$\mathrm{s}=\frac{\emptyset \cdot A v \cdot f y \cdot d}{V u-\emptyset V c}=\frac{0,75 \cdot 157 \cdot 400 \cdot 629}{367,474-157,2525}$

$=140,93 \mathrm{~mm}$

Digunakan $\mathrm{s}=125 \mathrm{~mm}$

$\mathrm{Vu}=\emptyset V s+\emptyset \mathrm{Vc}$

$=\frac{0,75.157 .400 .629}{125}+157,2525$

$=394,26 \mathrm{kN}$

$\mathrm{Vu}=367,474 \mathrm{kN}<\mathrm{Vu}=394,26 \mathrm{kN}$

Dari nilai yang didapatkan, maka tulangan sengkang yang digunakan adalah D10 - 125 $\mathrm{mm}$.

b. Balok induk arah Y

Dimensi balok : $0,6 \mathrm{~m} \mathrm{x} \mathrm{0,3} \mathrm{m}$

Gaya geser $(\mathrm{Vu}) \quad: 245,71 \mathrm{kN}$

Perhitungan tulangan geser yang diperlukan pada balok ini sama dengan perhitungan yang dilakukan pada balok induk arah $\mathrm{X}$.

c. Balok anak

Dimensi balok : $\quad 0,5 \mathrm{~m} \mathrm{x} 0,25 \mathrm{~m}$ Gaya geser $(\mathrm{Vu}) \quad: 112,814 \mathrm{kN}$

Perhitungan tulangan geser yang diperlukan pada balok ini sama dengan perhitungan yang dilakukan pada balok induk arah X.

\section{PENULANGAN KOLOM}

Tulangan kolom yang digunakan adalah baja tulangan ulir (deform) dengan mutu fy $=400$ Mpa untuk $\mathrm{D} \geq 10 \mathrm{~mm}$ dan mutu beton $\mathrm{fc}=$ $25 \mathrm{Mpa}$.

1. Penulangan kolom lantai

Data-data yang diperlukan untuk perencanaan penulangan kolom ini adalah:

Dimensi kolom $1=0,75 \mathrm{~m} \times 0,75 \mathrm{~m}$

Dimensi kolom $2=0,75 \mathrm{~m} \times 0,75 \mathrm{~m}$

Tinggi kolom bawah $=4,5 \mathrm{~m}$

Tinggi kolom atas $=4 \mathrm{~m}$

Dimensi balok kanan $=0,7 \mathrm{~m} \times 0,4 \mathrm{~m}$

Dimensi balok kiri $=0,7 \mathrm{~m} \mathrm{x} 0,4 \mathrm{~m}$

Panjang balok kanan $=8 \mathrm{~m}$

Panjang balok kiri $=8 \mathrm{~m}$

Dimensi tulangan $(\mathrm{D})=\mathrm{D} 22 \mathrm{~mm}$

Dimensi sengkang $(\mathrm{s}) \quad=\mathrm{D} 10 \mathrm{~mm}$

Selimut beton $(\mathrm{sb}) \quad=50 \mathrm{~mm}$

$\mathrm{d}=\mathrm{h}-\mathrm{sb}-\mathrm{D} / 2=750-50-11$

$=689 \mathrm{~mm}$

Beban-beban rencana:

Gaya aksial $(\mathrm{Pu})$ kolom bawah

$\mathrm{Pu}=5261,162 \mathrm{kN}=5261162 \mathrm{~N}$

Gaya aksial $(\mathrm{Pu})$ kolom atas

$\mathrm{Pu}=4453,672 \mathrm{kN}=4453672 \mathrm{~N}$

Gaya aksial $(\mathrm{Pu})$ balok kanan

$\mathrm{Pu}=0,2 \mathrm{kN}$ (akibat beban mati)

$\mathrm{Pu}=0,24 \mathrm{kN}$ (akibat kombinasi 2) 
Gaya aksial $(\mathrm{Pu})$ balok kiri

$\mathrm{Pu}=0,144 \mathrm{kN}$ (akibat beban mati)

$\mathrm{Pu}=0,173 \mathrm{kN}$ (akibat kombinasi 2)

Momen terkecil pada ujung kolom yang akan ditinjau,

$\mathrm{Mu}=-534,4495 \mathrm{kNm}$

$=-534449500 \mathrm{Nmm}$

Momen terbesar pada ujung kolom yang akan ditinjau,

$\mathrm{Mu}=199,5518 \mathrm{kNm}$

$=199551800 \mathrm{Nmm}$

Analisa struktur kolom

Kolom bawah

$\operatorname{Ig}=1 / 12 \cdot b \cdot h^{3}=\frac{1}{12} \times 750 \times 750^{3}$

$=2,63671875.10^{10} \mathrm{~mm}^{4}$

$\mathrm{Ec}=23500 \mathrm{Mpa}$

' $\beta=1$

$\mathrm{EI}=\frac{\frac{E c . I g}{2,5}}{1+\beta}=\frac{\frac{23500.2,63671875 \cdot 10^{10}}{2,5}}{1+1}$

$=1,239257813.10^{13} \mathrm{Nmm}^{2}$

Kolom atas

$\mathrm{Ig}=1 / 12 \cdot \mathrm{b} \cdot \mathrm{h}^{3}=\frac{1}{12} \times 750 \times 750^{3}$

$=2,63671875.10^{10} \mathrm{~mm}^{4}$

$\mathrm{Ec}=23500 \mathrm{Mpa}$

' $\beta=1$

$\mathrm{EI}=\frac{\frac{E c . I g}{2,5}}{1+\beta}=\frac{\frac{23500.2,63671875.10^{10}}{2,5}}{1+1}$

$=1,239257813.10^{13} \mathrm{Nmm}^{2}$

Balok kanan

$\mathrm{Ig}=1 / 12 \cdot b \cdot h^{3}=\frac{1}{12} \times 400 \times 700^{3}$

$=1,143333333 \cdot 10^{10} \mathrm{~mm}^{4}$

$\mathrm{Ec}=23500 \mathrm{Mpa}$

' $\beta=1$

$\mathrm{EI}=\frac{\frac{E c . \mathrm{Ig}}{2,5}}{1+\beta}=\frac{\frac{23500.1,143333333 \cdot 10^{10}}{2,5}}{1+1}$

$=5,373666665.10^{13} \mathrm{Nmm}^{2}$

Balok kiri

$\mathrm{Ig}=1 / 12 \cdot b \cdot h^{3}=\frac{1}{12} \times 400 \times 700^{3}$

$=1,143333333.10^{10} \mathrm{~mm}^{4}$

$\mathrm{Ec}=23500 \mathrm{Mpa}$

' $\beta=1$

$\mathrm{EI}=\frac{\frac{E c . I g}{2,5}}{1+\beta}=\frac{\frac{23500.1,143333333.10^{10}}{2,5}}{1+1}$

$=5,373666665 \cdot 10^{13} \mathrm{Nmm}^{2}$

Faktor kekangan ujung pada kolom, struktur merupakan kolom yang dapat bergoyang (SNI 03-2847-2002 12.11 pasal 6). Struktur kolom termasuk dalam struktur portal bergoyang, karena ukuran portal dan bebanbeban yang diterima oleh struktur tidak simetris. Hal ini menyebabkan faktor kekangan pada ujung atas kolom harus dicari terlebih dahulu.
$\Psi_{\mathrm{A}}=\frac{\frac{1,239257813.10^{13}}{4000}+\frac{1,239257813.10^{13}}{4500}}{\frac{5,373666665.10^{13}}{8000}+\frac{5,373666665.10^{13}}{8000}}$

$=0,436$

$\Psi_{\mathrm{B}}=0$, karena struktur kolom dengan perletakan jepit-jepit

Dari nomogram diperoleh faktor panjang efektif kolom, $\mathrm{k}=1,08$.

Menentukan angka kelangsingan kolom

$\mathrm{R}=0,3 \mathrm{~h}$ ( 0,3 untuk kolom persegi)

$=0,3 \times 750=225$

$\left(\frac{k \cdot l u}{r}\right)=\left(\frac{1,08 \times(4500-400)}{225}\right)<34-12 \cdot \frac{M 1}{M 2}$

$=19,68<34-12 . \frac{199,5518}{534,4495}$

$=19,68<29,52$

Dari nilai perbandingan tersebut, dapat disimpulkan bahwa kolom yang ditinjau termasuk kolom pendek.

Menentukan eksentrisitas kolom

$\mathrm{e}=\frac{M u}{P u}=\frac{534,4495}{5261,162}=101,6 \mathrm{~mm}$

e $\min =0,1 . h=0,1.750=75 \mathrm{~mm}$

Menghitung Pn perlu

$\mathrm{Ag}=\mathrm{b} \times \mathrm{h}=750 \times 750$

$=562500 \mathrm{~mm}^{2}$

0,1.Ag.fc $=0,1.562500 .25$

$=1406,25 \mathrm{kN}<\mathrm{Pu}=5261,162 \mathrm{kN}$

Digunakan faktor reduksi 0,65, maka didapatkan:

Pn perlu $=\frac{5261,162}{0,65}=8094,1 \mathrm{kN}$

$\mathrm{a}=\frac{\text { Pn perlu }}{0,85 \cdot f c \cdot b}=\frac{8094,1}{0,85 \cdot 25 \cdot 750}=507,87 \mathrm{~mm}$

As $=\frac{\text { Pn perlu } .\left(e-\frac{b}{2}+\frac{a}{2}\right)}{f y \cdot\left(d-d^{\prime}\right)}$

$=\frac{8094100 \cdot\left(101,6-\frac{750}{2}+\frac{507,87}{2}\right)}{400 .(689-71)}$

$=1398,1 \mathrm{~mm}^{2}$

As $=$ As'

Kontrol luas tulangan

Ast $=$ As + As' $=1398,1+1398,1$

$=2796,2 \mathrm{~mm}^{2}$

As $\min =1 \% \mathrm{Ag}=5625 \mathrm{~mm}^{2}$

As $\max =6 \% \mathrm{Ag}=33750 \mathrm{~mm}^{2}$

Nilai Ast < As min, maka luas tulangan yang digunakan harus sama dengan atau lebih besar dari luasan tulangan minimum.

Pola keruntuhan tekan menggunakan pendekatan whitney

$\mathrm{An}=\mathrm{Ag}-\mathrm{Ast}=562500-5625$

$=556875 \mathrm{~mm}^{2}$

Pno $=$ An $\times 0,85 \times \mathrm{fc}+$ Ast $\mathrm{x}$ fy

$=556875 \times 0,85 \times 25+5625 \times 400$

$=14083593,75 \mathrm{~N}=14083,6 \mathrm{kN}$

$\mathrm{Pn}=\frac{\text { Pno }}{1+\left(\frac{P n o}{P n p}-1\right) x \frac{e}{e b}}$ 
$=\frac{14083593,75}{1+\left(\frac{14083593,75}{8094100}-1\right) \times \frac{101,6}{156,31}}$

$=9509634,3 \mathrm{~N}=9509,6343 \mathrm{kN}$

Kontrol keamanan kolom

$\mathrm{Pu} \geq 0$,1.Ag.fc

$5261,162 \mathrm{kN} \geq 0,1.750 .750 .25$

$5261,162 \mathrm{kN} \geq 1406,25 \mathrm{kN}$

$\varnothing \mathrm{Pn}=0,65 \times 9509,6343$

$=6181,2923 \mathrm{kN}>\mathrm{Pu}=5261,162 \mathrm{kN}(\mathrm{aman})$

Diagram PM ratio

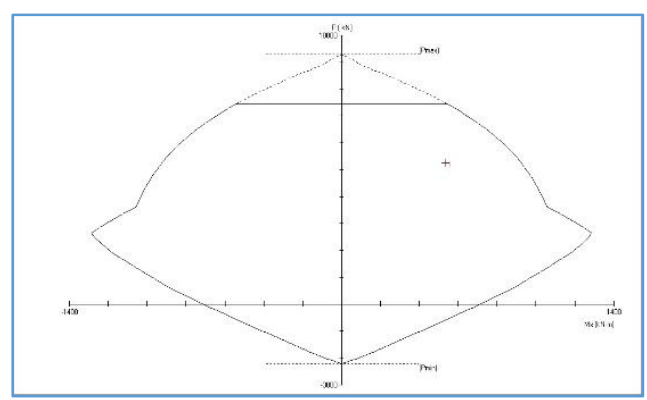

Grafik rasio tulangan kolom

Dari diagram yang dihasilkan oleh program PcaColoumn, berdasarkan dimensi kolom, jumlah tulangan, mutu beton, dan mutu baja yang digunakan, bisa disimpulkan bahwa kolom yang direncanakan memiliki rasio aksial maksimum dan momen maksimum berada pada area grafik yang aman.

Penulangan kolom

Tulangan pokok

As perlu $=1 \% \times \mathrm{b} \mathrm{x} \mathrm{h}$

$=0,01.750 .750$

$=5625 \mathrm{~mm}^{2}$

Jumlah tulangan yang diperlukan adalah:

$\mathrm{n}=\frac{\text { As perlu }}{\text { Luas tulangan }}=\frac{5625}{380,286}=14,7915$

Karena tulangan kolom dipasang pada keempat sisi, jadi tulangan yang digunakan adalah $16 \mathrm{D} 22 \mathrm{~mm}$.

Menghitung nilai $\varphi$ Pn maksimum

Luas tulangan yang digunakan (Ast)

Ast $=\mathrm{n} \times$ Luas tulangan

$=16 \times 380,286$

$=6084,576 \mathrm{~mm}^{2}$

$\mathrm{Pn}=0,80 \cdot\left(0,85 \cdot \mathrm{fc}^{\prime} \cdot(\right.$ ag-ast $\left.)+\mathrm{fy} \cdot \mathrm{ast}\right)$

$=0,8 \cdot(0,85 \cdot 25 \cdot(562500-6084,576)$

$+400.6084,576$

$=11406126,53 \mathrm{~N}=11406,12653 \mathrm{kN}$

$\Phi P n=0,85.11406,12653$

$=9695,208 \mathrm{kN}$

Dari hasil perhitungan dimensi dengan dibandingkan dengan perhitungan $\mathrm{Pu}$ terbesar, dengan syarat bahwa $\Phi \mathrm{Pn} \geq \mathrm{Pu}$
$\Phi P n=9695,208 \mathrm{kN} \geq \mathrm{Pu}$ terbesar $=$ $5261,162 \mathrm{kN}$ (aman)

Tulangan sengkang kolom

Gaya geser perlu kolom ( Vu)

$\mathrm{Vu}=\frac{M u 2-M u 1}{\lambda \mathrm{n} \mathrm{k}}=\frac{199,5518-(-534,4495)}{4,5}$

$=163,1114 \mathrm{kN} \sim 163111,4 \mathrm{~N}$

Gaya geser yang ditahan oleh beton $(\mathrm{Vc})$

$\mathrm{Vc}=\left(1+\frac{P u, k}{14 \cdot A g}\right) \frac{\sqrt{f c^{\prime}}}{6} \cdot b \cdot d$

$=\left(1+\frac{5261162}{14.750 .750}\right) \frac{\sqrt{25}}{6} \cdot 750.689$

$=718318,6998 \mathrm{~N}$

Gaya geser yang ditahan oleh sengkang (Vs) dan Vs maks

$\mathrm{Vs}=\frac{V u-\phi . V c}{\phi}=\frac{163111,4-0,75.718318,6998}{0,75}$

$=-500836,8331 \mathrm{~N}$

Vs maks $=\frac{2}{3} \cdot \sqrt{f c^{\prime}} \cdot b \cdot d$

$=\frac{2}{3} \cdot \sqrt{25} \cdot 750.689=1722500 \mathrm{~N}$

Karena Vs $<$, maka dipakai tulangan sengkang mininal dengan luas per meter panjang seperti berikut:

Luas tulangan sengkang perlu (Avu) untuk setiap panjang kolom

$\mathrm{S}=1000 \mathrm{~mm}$

$\mathrm{Av}=\frac{b . S}{f y .3}=\frac{750.1000}{400.3}=625 \mathrm{~mm}^{2}$

$\mathrm{Av}=\frac{75 \sqrt{f c^{\prime}} \cdot b \cdot S}{1200 \cdot f y}=\frac{75 \cdot \sqrt{25} \cdot 750 \cdot 1000}{1200 \cdot 400}$

$=585,9375 \mathrm{~mm}^{2}$

Dari kedua Av dipilih yang paling besar, yaitu $\mathrm{Avu}=625 \mathrm{~mm}^{2}$

Digunakan tulangan sengkang 2 kaki dengan $\mathrm{dp}=10 \mathrm{~mm}$ dengan jarang sengkang yaitu:

$\mathrm{S}=\frac{\frac{n}{4} \cdot \pi \cdot d p^{2} \cdot S}{A v, u}=\frac{\frac{2}{4} \cdot 3,14 \cdot 10^{2} \cdot 1000}{625}$

$=251,327 \mathrm{~mm}$

Kontrol jarak tulangan sengkang

$\mathrm{s} \leq 16 . \mathrm{D}=16.22=352 \mathrm{~mm}$

$\mathrm{s} \leq 48 . \mathrm{dp}=48.10=480 \mathrm{~mm}$

$\mathrm{s} \leq \mathrm{d} / 2=689 / 2=344,5 \mathrm{~mm}$

$\mathrm{s} \leq 600 \mathrm{~mm}$

Dipakai nilai terkecil dan dibulatkan ke bawah yaitu:

$\mathrm{s}=250 \mathrm{~mm}<251,327 \mathrm{~mm}$

Jadi digunakan tulangan sengkang D10 $250 \mathrm{~mm}$.

2. Penulangan kolom atap

Data-data yang diperlukan untuk perencanaan penulangan kolom ini adalah:

Dimensi kolom $1=0,3 \mathrm{~m} \times 0,3 \mathrm{~m}$

Tinggi kolom $1=2,5 \mathrm{~m}$

Dimensi balok $1=0,5 \mathrm{~m} \times 0,25 \mathrm{~m}$

Panjang balok $1=5,7 \mathrm{~m}$ 
Dimensi tulangan $(\mathrm{D}) \quad=\quad \mathrm{D} 22 \mathrm{~mm}$ Dimensi sengkang $(\mathrm{s}) \quad=\mathrm{D} 10 \mathrm{~mm}$

Selimut beton $(\mathrm{sb})=50 \mathrm{~mm}$

$\mathrm{d}=\mathrm{h}-\mathrm{sb}-\mathrm{D} / 2=300-50-11$

$=239 \mathrm{~mm}$

$\mathrm{d}_{\mathrm{s}}=\mathrm{sb}+\mathrm{s}+\mathrm{D} / 2=50+10+11$

$=71 \mathrm{~mm}$

Beban-beban rencana:

Gaya aksial $(\mathrm{Pu})$

$\mathrm{Pu}=156,701 \mathrm{kN}=1567010 \mathrm{~N}$

Gaya aksial $(\mathrm{Pu})$ balok kiri

$\mathrm{Pu}=0,044 \mathrm{kN}$ (akibat beban mati)

$\mathrm{Pu}=0,063 \mathrm{kN}$ (akibat kombinasi 2)

Momen terkecil pada ujung kolom,

$\mathrm{Mu}_{1}=-55,338 \mathrm{kNm}$

$=-55338000 \mathrm{Nmm}$

Momen terbesar pada ujung kolom,

$\mathrm{Mu}_{2}=62,4596 \mathrm{kNm}$

$=62459600 \mathrm{Nmm}$

Dengan menggunakan rumus-rumus seperti pada perhitungan penulangan kolom lantai, maka data-data tulangan pokok, kontrol tulangan, dan tulangan gesek dapat dihitung.

\section{RENCANA ANGGARAN BIAYA}

\begin{tabular}{|c|c|c|c|c|}
\hline \multirow{2}{*}{ No. } & \multirow{2}{*}{ URAIAN } & \multirow{2}{*}{ SATUAN } & \multirow{2}{*}{ VOLLME } & \multirow{2}{*}{$\begin{array}{c}\text { JUMLAH HARGA } \\
(\mathbb{R p} .)\end{array}$} \\
\hline & & & & \\
\hline 1. & 2. & 3. & 4. & $6=(4 . X 5)$. \\
\hline & \begin{tabular}{|l|l|l|} 
PEKERJAAN LANTAI2 & & \\
\end{tabular} & & & \\
\hline & \begin{tabular}{|l|l|}
1 & Pekerjaan Balok $700 \mathrm{~mm} \times 4000 \mathrm{~mm}$ \\
\end{tabular} & & & $62,125,043,75$ \\
\hline & \begin{tabular}{|l|l|}
2 & Pekerjaan Balok $600 \mathrm{~mm} \times 300 \mathrm{~mm}$
\end{tabular} & & & $33,286,433,33$ \\
\hline & \begin{tabular}{l|l}
3 & Pekerjaan Balok Anak $500 \mathrm{~mm} \times 250 \mathrm{~mm}$
\end{tabular} & & & $45,041,654,76$ \\
\hline & \begin{tabular}{|l|l|}
4 & Pekerjaan Kolom $750 \mathrm{~mm} \times 750 \mathrm{~mm}$ \\
\end{tabular} & & & $104,581,041,68$ \\
\hline & \begin{tabular}{|l|l}
5 & Pekerjaan Pelat Lantai Tebal $12 \mathrm{~cm}$ \\
\end{tabular} & & & $90,627,138.58$ \\
\hline \multirow[t]{6}{*}{2} & \begin{tabular}{|l|l|l|} 
PEKERJAANLANTAI 3 & & \\
\end{tabular} & & & \\
\hline & \begin{tabular}{|l|l}
1 & Pekeriaan Balok $700 \mathrm{~mm} \times \mathrm{x} 400 \mathrm{~mm}$ \\
\end{tabular} & & & $63,931,043,75$ \\
\hline & \begin{tabular}{|l|l|l}
2 & Pekerjaan Balok $600 \mathrm{~mm} \times 300 \mathrm{~mm}$ \\
\end{tabular} & & & $33,286,433,33$ \\
\hline & \begin{tabular}{l|l}
3 & Pekerjaan Balok Anak $500 \mathrm{~mm} \times 250 \mathrm{~mm}$ \\
\end{tabular} & & & $43,756,492.26$ \\
\hline & \begin{tabular}{l|l|}
4 & Pekerjaan Kolom $750 \mathrm{~mm} \times 750 \mathrm{~mm}$
\end{tabular} & & & $91,955,958,32$ \\
\hline & \begin{tabular}{c|c}
5 & Pekrerjan Pelat Lantai Tehal $12 \mathrm{~cm}$ \\
\end{tabular} & & & $90,460,264.18$ \\
\hline \multirow[t]{6}{*}{3} & \begin{tabular}{|l|l|} 
PEKERJAN LANTII4 & \\
\end{tabular} & & & \\
\hline & 1 Pekerjaan Balok $700 \mathrm{~mm} \times 400 \mathrm{~mm}$ & & & $62,185,2437.75$ \\
\hline & $\begin{array}{lll}2 & \text { Pekerjaan Balok } 600 \mathrm{~mm} \times 300 \mathrm{~mm} \\
\end{array}$ & & & 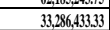 \\
\hline & \begin{tabular}{l|l}
3 & Pekerjaan Balok Anak $500 \mathrm{~mm} \times 250 \mathrm{~mm}$
\end{tabular} & & & $44,305,279.76$ \\
\hline & \begin{tabular}{l|l|}
4 & Pekerjaan Kolom $750 \mathrm{~mm} \times 750 \mathrm{~mm}$ \\
\end{tabular} & & & $101,669,041.68$ \\
\hline & \begin{tabular}{|l|l|}
5 & Pekerjan Pelat Lantai Tehal $12 \mathrm{~cm}$ \\
\end{tabular} & & & $91,120,047.58$ \\
\hline \multirow[t]{6}{*}{4} & \begin{tabular}{|l|l|l|} 
PEKERJAAN LANTAI5 & & \\
\end{tabular} & & & \\
\hline & 1 Pekerjaan Balok $700 \mathrm{~mm} \times 100 \mathrm{~mm}$ & & & $62,185,243,75$ \\
\hline & \begin{tabular}{l|l}
2 & Pekerjan Balok $600 \mathrm{~mm} \times 300 \mathrm{~mm}$ \\
\end{tabular} & & & $33.286,43333$ \\
\hline & $\begin{array}{ll}3 & \text { Pekerjaan Balok Anak } 500 \mathrm{~mm} \times 250 \mathrm{~mm}\end{array}$ & & & $42,859,404,76$ \\
\hline & \begin{tabular}{|l|l|}
4 & Pekerjaan Kolom $750 \mathrm{~mm} \times 750 \mathrm{~mm}$
\end{tabular} & & & $91,955,958.32$ \\
\hline & \begin{tabular}{|c|c|}
5 & Pekerjaan Pelat Lantai Tehal $12 \mathrm{~cm}$ \\
\end{tabular} & & & $90,96,444.78$ \\
\hline \multirow[t]{6}{*}{5} & \begin{tabular}{|l|l|l|} 
PEKERJANLANTII 6 & & \\
\end{tabular} & & & \\
\hline & \begin{tabular}{|l|l}
1 & Pekerian Balok $700 \mathrm{~mm} \times 400 \mathrm{~mm}$ \\
\end{tabular} & & & $62.185,243,75$ \\
\hline & 2 Pekerjaan Balok $600 \mathrm{~mm} \times 300 \mathrm{~mm}$ & & & $33,286,433,33$ \\
\hline & \begin{tabular}{l|l}
3 & Pekerjaan Balok Anak $500 \mathrm{~mm} \times 250 \mathrm{~mm}$ \\
\end{tabular} & & & $41,217,799,76$ \\
\hline & \begin{tabular}{l|l|}
4 & Pekerjaan Kolom $750 \mathrm{~mm} \times 750 \mathrm{~mm}$
\end{tabular} & & & 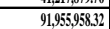 \\
\hline & \begin{tabular}{c|c}
5 & Pekerjaan Pelat Lantai Tebal $12 \mathrm{~cm}$ \\
\end{tabular} & & & $91,437,155,38$ \\
\hline \multirow[t]{6}{*}{6} & \begin{tabular}{|l|l|l|} 
PEKERJAAN LANTAI7 7 & & \\
\end{tabular} & & & \\
\hline & 1 Pekerjaan Balok $700 \mathrm{~mm} \times 400 \mathrm{~mm}$ & & & $62,185,243,75$ \\
\hline & $\begin{array}{lll}2 & \text { Pekerjaan Balok } 600 \mathrm{~mm} \times 300 \mathrm{~mm} \\
\end{array}$ & & & 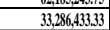 \\
\hline & \begin{tabular}{c|c}
3 & Pekerjaan Balok Anak $500 \mathrm{~mm} \times 250 \mathrm{~mm}$
\end{tabular} & & & $39,873,054,76$ \\
\hline & \begin{tabular}{l|l|}
4 & Pekerjaan Kolom $750 \mathrm{~mm} \times \mathrm{m} 750 \mathrm{~mm}$ \\
\end{tabular} & & & $91,955,958.32$ \\
\hline & \begin{tabular}{|c|c|}
5 & Pekerjaan Pelat Lantai Tebal $12 \mathrm{~cm}$ \\
\end{tabular} & & & $91,50,829,78$ \\
\hline \multirow[t]{6}{*}{7} & PEKERJANNLANTAI DAK & & & \\
\hline & 1 Pekerjan Balok $700 \mathrm{~mm} \times 400 \mathrm{~mm}$ & & & $60,439,43,75$ \\
\hline & \begin{tabular}{ll|l}
2 & Pekerjaan Balok $600 \mathrm{~mm} \times 300 \mathrm{~mm}$ \\
\end{tabular} & & & $35,600,693,33$ \\
\hline & \begin{tabular}{l|l}
3 & Pekerjaan Balok Anak $500 \mathrm{~mm} \times 250 \mathrm{~mm}$ \\
\end{tabular} & & & $33,618,16,26$ \\
\hline & $\begin{array}{lll}4 & \text { Pekerjaan Kolom } 750 \mathrm{~mm} \times \mathrm{750} \mathrm{mm}\end{array}$ & & & $91,955,958,32$ \\
\hline & \begin{tabular}{l|l}
5 & Pekerjaan Pelat Lantai Tebal $12 \mathrm{~cm}$ \\
\end{tabular} & & & 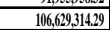 \\
\hline \multicolumn{4}{|c|}{ Jumlah total } & $2,226,894,145.3$ \\
\hline
\end{tabular}

Rencana anggaran biaya yang diperlukan untuk membangun struktur atas gedung Rumah Sakit Umum Kelas D Kecamatan
Pasar Minggu Jakarta Selatan adalah Rp. 2.666.235.721,- dan waktu yang diperlukan adalah 21 minggu atau 5 bulan 1 minggu.

D. Kesimpulan :

1. Kolom lantai 1-7 menggunakan dimensi $750 \mathrm{~mm}$ x $750 \mathrm{~mm}$ direncanakan 16 D22 $\mathrm{mm}$, pada desain awal digunakan dimensi $750 \mathrm{~mm}$ x $750 \mathrm{~mm}$ dengan tulangan 20 D25 mm.

2. Kolom atap menggunakan dimensi 300 $\mathrm{mm}$ x $300 \mathrm{~mm}$ direncanakan $6 \mathrm{D} 22 \mathrm{~mm}$, pada desain awal digunakan dimensi 300 $\mathrm{mm} \times 300 \mathrm{~mm}$ dengan tulangan $6 \mathrm{D} 16$ $\mathrm{mm}$.

3. Balok induk arah " $\mathrm{X}$ " menggunakan dimensi $400 \mathrm{~mm}$ x $700 \mathrm{~mm}$ dengan menggunakan tulangan:

a. Daerah tumpuan menggunakan tulangan 13 D22 mm, 8 D22 mm di daerah atas dan 5 D22 $\mathrm{mm}$ di daerah bawah.

b. Daerah lapangan menggunakan tulangan 6 D22 mm, 2 D22 $\mathrm{mm}$ di daerah atas dan 4 D22 $\mathrm{mm}$ di daerah bawah.

4. Balok induk arah "Y" menggunakan dimensi $300 \mathrm{~mm}$ x $600 \mathrm{~mm}$ dengan menggunakan tulangan:

a. Daerah tumpuan menggunakan tulangan 7 D22 mm, 4 D22 mm di daerah atas dan $3 \mathrm{D} 22 \mathrm{~mm}$ di daerah bawah.

b. Daerah lapangan menggunakan tulangan 5 D22 mm, 2 D22 $\mathrm{mm}$ di daerah atas dan 3 D22 $\mathrm{mm}$ di daerah bawah.

5. Balok anak menggunakan dimensi 250 $\mathrm{mm}$ x $500 \mathrm{~mm}$ dengan menggunakan tulangan:

a. Daerah tumpuan menggunakan tulangan 5 D19 mm, 3 D19 mm di daerah atas dan 2 D19 $\mathrm{mm}$ di daerah bawah.

b. Daerah lapangan menggunakan tulangan 6 D19 mm, 2 D19 mm di daerah atas dan 4 D19 $\mathrm{mm}$ di daerah bawah.

6. Pelat lantai untuk lantai $2,4,5,6,7$, dan dak, tulangan yang digunakan adalah tulangan rangkap, yaitu:
a. Daerah lapangan arah $\mathrm{x}$ menggunakan tulangan D10 - 200 $\mathrm{mm}$ 
b. Daerah tumpuan arah $\mathrm{x}$ menggunakan tulangan D10 - $200 \mathrm{~mm}$

c. Daerah lapangan arah y menggunakan tulangan D10 - 200 $\mathrm{mm}$

d. Daerah tumpuan arah y menggunakan tulangan D10-200 mm

e. Daerah tumpuan arah $\mathrm{x}$ menggunakan tulangan D10 - $150 \mathrm{~mm}$

f. Daerah lapangan arah y menggunakan tulangan D10 - 200 $\mathrm{mm}$

g. Daerah tumpuan arah y menggunakan tulangan D10 - $50 \mathrm{~mm}$

7. Pelat untuk atap, tulangan yang digunakan adalah tulangan rangkap, yaitu:

a. Daerah lapangan arah $\mathrm{x}$ menggunakan tulangan D10 - 200 $\mathrm{mm}$

b. Daerah tumpuan arah $\mathrm{x}$ menggunakan tulangan D10 - $200 \mathrm{~mm}$

c. Daerah lapangan arah y menggunakan tulangan D10 - 200 $\mathrm{mm}$

d. Daerah tumpuan arah y menggunakan tulangan D10 - $200 \mathrm{~mm}$

E. SARAN :

1. Dibutuhkan literatur dan sumber referensi yang mendukung dalam penulisan tugas akhir ini supaya mempermudah sistem analisis yang dilakukan.

2. Dalam merencanakan suatu bangunan harus diketahui fungsi/kegunaan bangunan tersebut, supaya dalam tahap perhitungan mampu mendekati kesempurnaan tanpa kegagalan struktur

3. Dalam perhitungan menggunakan program harus, selalu dipastikan bahwa data material, beban-beban yang bekerja dan faktor reduksi yang diinput kedalam program SAP 2000 v.15 3D harus disesuaikan dengan peraturan yang berlaku di Indonesia (SK-SNI).

4. Suatu struktur bangunan yang kokoh dan kuat memerlukan suatu perencanaan struktur yang baik dengan menggunakan peraturan- peraturan perencanaan secara tepat dan benar.

5. Pemodelan dan pembebanan sangat berpengaruh terhadap benar atau tidaknya hasil perhitungan yang akan diperoleh. Kesalahan pada kedua hal tersebut mengakibatkan kesalahan padan dimensi akhir walaupun perhitungan yang telah dilakukan sudah benar.

6. Menguasai aplikasi atau program hitungan yang digunakan untuk memperlancar proses pengerjaan.

\section{F. DAFTAR PUSTAKA}

Asroni, A. 2010. Balok dan Pelat Beton Bertulang. Graha Ilmu. Yogyakarta.

Asroni Ali. 1998. Balok dan Pelat Beton Bertulang. Jakarta: Erlangga

Imran, Iswandi, Perencanaan Struktur Gedung Beton Bertulang Tahan Gempa, Penerbit ITB, Bandung, 2010.

Kusu, Gideon. 1993. Dasar-dasar Perencanaan Beton Bertulang, Penerbit Erlangga, Jakarta.

Manulang, Rio. 2010. Buku Pintar Rencana Anggaran Biaya (RAB), Penerbit Erlangga, Jakarta.

SNI 03-1726-2002. Tata Cara Perencanaan Ketahanan Gempa Untuk Bangunan Gedung. Badan Standardisasi Nasional

SNI 03-1729-2002. Tata Cara Perencanaan Struktur Baja untuk Bangunan Gedung. Departemen Pekerjaan Umum

SNI 03-2847-2002. Tata Cara Perhitungan Struktur Beton untuk Bangunan Gedung. Badan Standardisasi Nasional

SNI 1727-1989. Tata Cara Perencanaan Pembebanan untuk Rumah dan Gedung. Badan Standardisasi Nasional 